\title{
Pemanfaatan Kardus Menjadi Tempat Sampah Pintar Berbasis Arduino Uno R3
}

\author{
Tifani Intan Solihati, Ida Nuraida, Nur Hidayanti \\ Universitas Banten Jaya, JI Syech Nawawi Albantani Serang, Banten, Indonesia \\ Email: tifaniintansolihati@unbaja.ac.id, idanuraida@unbaja.ac.id, nurhidayanti@unbaja.ac.id
}

\begin{abstract}
The object of the research is industrial waste and human produce waste have been used often in the environment slum, and unsightly. The problems of Garbage interferes with the air pollution, and the environment is healthy, therefore that needs the other innovation to use the waste or garbage, and one of the waste is the cardboard. The cardboard waste includes to the one of the waste advantages for the result of the craft industry. The purposes of the research are to reduce unused cardboard in the community, to design smart trash cans using Ardruino Uno and to maintain environmental health and cleanliness. The methods of the research used the waterfall model. The steps are: Analysis, design, coding, treatment and testing tools. In this research, it was explained how to design smart bins that could function to attract the public in general and the students of Universitas Banten Jaya to dispose of their places using Arduino Uno R3. Another benefit is to make people aware of the importance of health by removing trash. The result of the research is the structural system of the garbage used microcontroller Ardunio and ultrasonic censoring, consisting of hardware and software including source code Arduino. Block diagram bases Arduino Uno R3 consist of servo, buzzer, and Arduino.
\end{abstract}

Keywords: Arduino Uno R3, Garbage, Processing, Cardboard, Microcontroller

\begin{abstract}
Abstrak
Limbah industri dan sampah yang dihasilkan manusia sering membuat lingkungan kumuh serta menjadi tidak sehat. Permasalahan yang muncul terkait sampah yaitu polusi udara, dan kesehatan manusia serta lingkungan. Untuk itu dibutuhkan inovasi lain untuk memanfaatkan sampah. Salah satu benda yang dimaksud adalah kardus. Sampah berupa kardus merupakan salah satu sampah yang banyak digunakan untuk industri kerajinan. Tujuan dari penelitian ini adalah mengurangi kardus tidak terpakai di lingkungan masyarakat, merancang tempat sampah pintar menggunakan Arduino Uno dan untuk menjaga kesehatan dan kebersihan lingkungan. Metode yang digunakan dalam penelitian ini yaitu menggunakan model waterfall. Alasan dari penggunaan metode waterfall adalah karena metode ini tersusun secara lengkap step by step nya, sehingga bisa meminimalisir kesalahan yang akan terjadi. Dengan Tahapan sebagai berikut: Analisis, desain, coding, pengujian, perawatan. Dalam penelitian ini, telah dijelaskan bahwa penempatan penggunaan Arduino Uno R3 yang merupakan kebermanfaatan untuk kesehatan lingkungan dengan cara mengolah sampah dan disosialisasikan kepada masyarakat oleh mahasiswa Universitas Banten Jaya mengenai penggunaan Ardruino Uno R3. Hasil penelitian ini adalah berupa struktur atau desain sistem untuk sampah dengan menggunakan ardruino Uno R3 yang terdiri dari perangkat keras dan perangkat lunak untuk source code arduino, diagram blok arduino Uno R3 yang terdiri dari servo, buzzer, dan arduino.
\end{abstract}

Kata Kunci: Arduino Uno R3, Sampah, Pengolahan, Kardus, Mikrokontroller 


\section{PENDAHULUAN}

Tempat sampah konvensional yang telah ada, tidak difungsikan sebagai mana mestinya dan hanya menjadi hiasan di tempat-tempat umum. Dalam meningkatkan kesadarang dan kepedulian terhadap kebersihan lingkungan, diperlukan cara yang unik agar tiap-tiap individu dapat tertarik dan tidak segan dalam membuang sampah pada tempatnya. Dengan membuat cara unik, bisa membantu untuk kelestarian lingkungan. Dengan menggunakan benda yang telah tidak dipakai sering membuat lingkungan kumuh, rusuh dan membuat lingkungan tidak sedap dipandang mata. Untuk itu butuh inovasi lain untuk memanfaatkan limbah atau sampah. Salah satu benda yang dimaksud adalah kardus. Limbah kardus merupakan salah satu limbah sampah yang banyak digunakan industri kerajinan yang dihasilkan. Walaupun sebagai industri kerajinan dengan modal terbatas, industri ini banyak memberikan value riset terutama kepada pemerintahan dan perekonomian negara dengan menyerap banyak tenaga kerja.

Hasil kerajinan industri sebelumnya seperti tempat sampah, pot bunga serta anyaman meja dan kursi, namun sebagian besar penggagas yang bergerak dalam industri kerajinan limbah kardus kadang memiliki kendala dengan modal terbatas dan riset konsumen yang begitu sulit untuk menembus pasar maka perhatian terhadap pengelolaan industri kerajinan sangat tidak diperhatikan, maka perhatian ini kami kembangkan dengan menggagas ide dengan lebih memanfaatkan limbah kardus dan sedikit kreativitas dibuat menjadi tempat sampah pintar dengan kardus tidak terpakai yang masih bisa dimanfaatkan. Akan tetapi masyarakat masih kurang menyadari peluang usaha dari kardus tidak terpakai itu sendiri. Padahal masyarakat bisa saja sedikit demi sedikit dapat memanfaatkan kardus tidak terpakai menjadi sesuatu yang dapat dijadikan peluang usaha, jika kita melihat kondisi yang sedang terjadi di Indonesia yaitu adanya virus Covid-19 yang berdampak besar pada perekonomian masyarakat saat ini, apalagi pada masyarakat menengah kebawah. Banyak dari mereka yang kehilangan mata pencaharian sehingga sangat sulit bagi mereka untuk menghadapi keadaan seperti sekarang ini. Meskipun pemerintah sudah berupaya untuk memberikan bantuan kepada masyarakat yang terdampak wabah virus Covid-19. Hal ini juga bisa memicu pemanasan global yang membuat terjadinya perubahan iklim dan diperkirakan akan semakin menjadi masalah besar jika upaya untuk menanggulanginya tidak ada (Putra \& Wahid, 2019).

Arduino Uno R3 adalah merupakan sebuah microcontroller yang memproses input yang diberikan melalui Bahasa pemrograman open source sehingga akan menghasilkan output yang diinginkan (Nusyirwan, 2020). Dan cukup menghubungkan Arduino dengan kabel USB ke PC, selanjutnya jalankan software Arduino untuk memprogram chip ATmega328. Arduino Uno juga bisa dikatakan sebagai salah satu produk berlabel Arduino yang sebenarnya adalah suatu papan elektronik yang mengandung microcontroller ATmega328 (Kholifah, 2015).

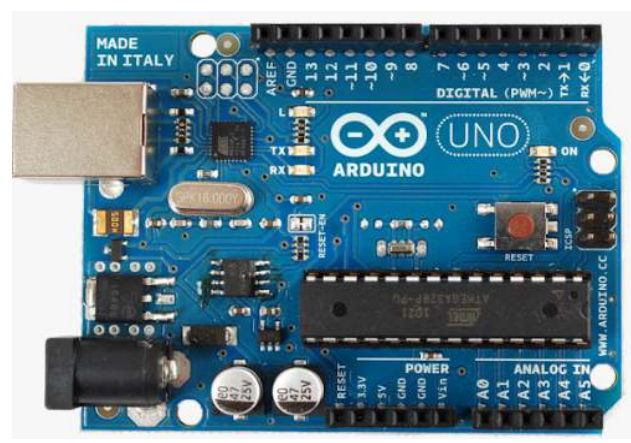

Gambar 1. Contoh Arduino Uno 
Sensor merupakan peralatan yang digunakan untuk mengubah suatu besaran fisik menjadi besaran listrik, sehingga dapat dianalisa dengan rangkaian listrik tertentu (Budiarso \& Prihandono, 2015). Sensor ultrasonik adalah merupakan sensor yang bekerja berdasarkan sebuah prinsip pantulan gelombang suara dan digunakan untuk mendeteksi keberadaan suatu objek atau benda tertentu yang ada didepan frekuensi kerja pada daerah diatas gelombang suara $20 \mathrm{kHz}$ hingga $2 \mathrm{MHz}$ (Arsada, 2017).

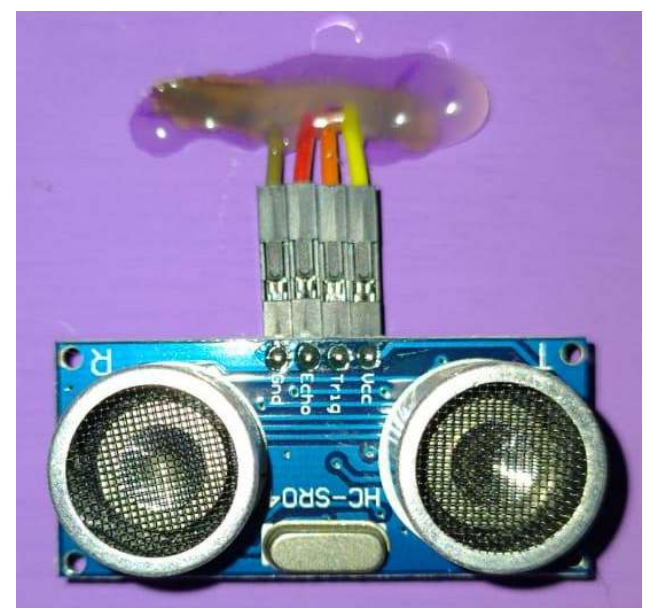

Gambar 2. Sensor Ultrasonik

Mikro Servo merupakan sebuah motor DC yang dilengkapi dengan rangkaian kendali (Nusyirwan, 2020). Motor servo disusun dari sebuah motor DC, roda gigi, potensiometer dan rangkaian control. Potensiometer juga memiliki fungsi untuk menentukan batas maksimum putaran sumbu motor.

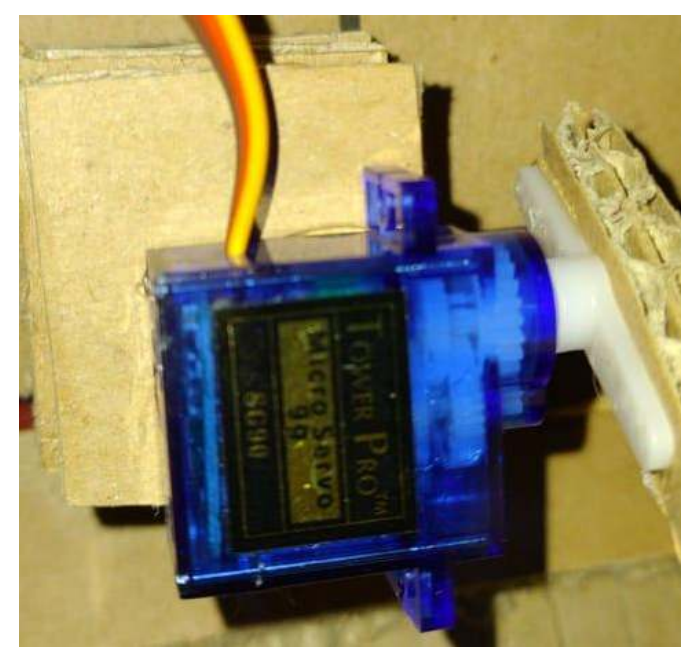

Gambar 3. Micro Servo

Perancangan sistem tempat sampah pintar dengan sensor HCRSF04 berbasis arduino uno, menggunakan sensor HC- SRO4 dalam meningkatkan kesadaran akan kepedulian terhadap kebersihan lingkungan. Oleh karena itu kita bisa memanfaatkan kardus tidak terpakai dengan cara berinovasi dan mengkreatifitaskan kardus tidak terpakai menjadi barang yang berguna. Maka dari itu kami membuat produk dari kardus tidak terpakai yang memiliki nilai ekonomis yang lebih tinggi (Wuryanto, Hidayatun, Rosmiati, \& Maysaroh, 2019). Pada produk alat pemilah sampah otomatis berbasis Arduino Meg Atmega 2560 yang dibuat untuk pemilah sampah dengan pusat kendali sensor proximity inductive sebagai alat pemilah sampah logam/metal, dan sensor prixomity capacitive sebagai alat pemilah sampah organik, 
serta sampah yang tidak terdeteksi oleh sensor masuk ke bak penampungan sampah organik (Nugroho, Pamungkas, \& Purbaningtyas, 2018). Lain hal pada sistem kontrol tempat sampah otomatis dengan supply utama arus listrik bisa menggunakan baterai yang bisa di isi ulang, hal ini bertujuan untuk pengurangan ketergantungan pemakaian listrik dari PLN. Juga peningkatan dari segi sensitifitas sensor saat membaca akan adanya objek, karena dibutuhkan waktu beberapa detik untuk mendeteksi gerakan objek (Hidayat \& Syahrani, 2017).

Tujuan dari dibuatnya tempat sampah otomatis ini selain untuk menanggulangi pencemaran lingkungan kardus tidak terpakai, juga membuat hal yang menarik masyarakat untuk giat membuang sampah pada tepatnya dan menjadikan lingkungan bersih dan indah dengan menggunakan Arduino Uno.

\section{METODE}

Metode perancangan aplikasi yang digunakan pada penelitian ini adalah waterfall.

Metode waterfall adalah merupakan suatu proses pengembangan perangkat lunak yang berurutan, dimana kemajuan teknologi dipandang sebagai terus mengalir ke bawah (seperti air terjun) dengan melewati beberapa fase-fase perencanaan, pemodelan implementasi dan pengujian (Prayitno \& Safitri, 2015). Pemilihan metode waterfall ini dikarenakan metode ini

sangat mudah dipahami dan metode ini sangat berurutan dari satu tahap ke tahap berikutnya secara rinci dengan meminimalisir kesalahan dalam proses pembuatan sistem.

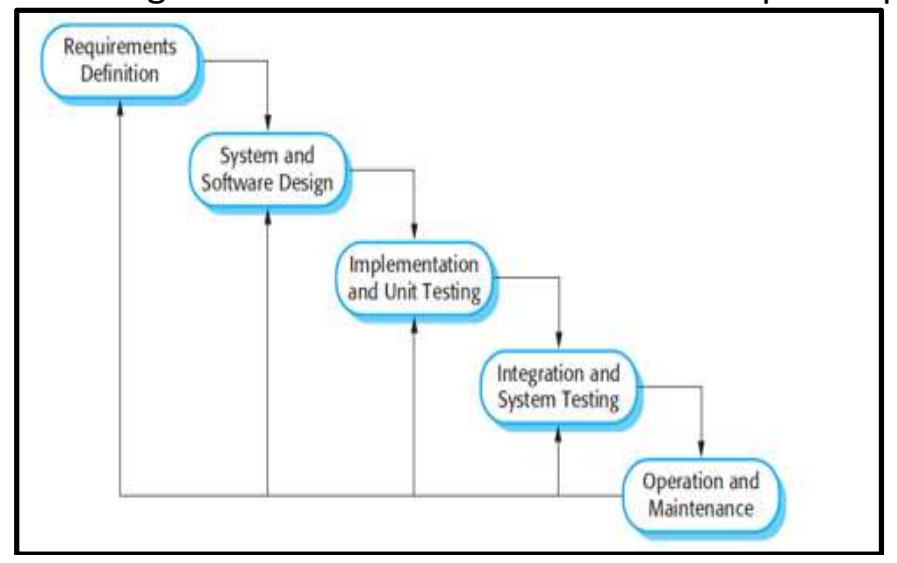

Gambar 4. Metode waterfall

Metodologi penelitian ini dengan menggunakan beberapa tahapan, yaitu adalah sebagai berikut:

1. Analisis

Peneliti mencoba menggunakan sistem yang berupa alat mikrokontroler Arduino UNO R3 sebagai alat pendeteksi, jumlah sampah sebagai otak dari sistem menggunakan software Arduino.

2. Desain

Perancangan elektrikal dirancang sesuai sketsa gambar sebagai acuan alat tempat sampah dengan sistem prototype.

3. Coding

Software Arduuino IDE dilakukan dengan pengkodean dengan memasukan coding ke dalam arduino dengan menggunakan bahasa pemrograman $\mathrm{C}$.

4. Pengujian.

Tahapan pengajuan terhadap coding dengan tahapan pengujian satu persatu.

5. Perawatan. 
Tahapan perawatan alat tempat sampah pintar di simpan pada tempat yang baik.

Metode untuk tahapan pengumpulan data menggunakan beberapa tahapan penelitian yaitu sebagai berikut:

1. Observasi

Untuk pengumpulan data yang melalui beberapa tahapan, yaitu tahapan penulisan dan tahapan tujuannya reduksi untuk mendeskripsikan objek yang menjadi tempat penelitian.

2. Wawancara

Untuk tahapan pengumpulan data selanjutnya yaitu melakukan wawancara yang menjadi instrumen untuk mendapat informasi secara lisan.

3. Studi Pustaka

Tahapan selanjutnya yaitu mengumpulkan sumber informasi berdasarkan referensi yang terkait dengan pengolahan sampah.

\section{HASIL DAN PEMBAHASAN}

Desain Sistem

1. Deskripsi Desain Sistem

Tempat sampah pintar di desain dengan ardruino yang terdiri dari desain perangkat keras atau hardware yang meliputi desain alat dan software atau perangkat lunak yaitu berupa arduino source code.

2. Deskripsi Diagram Blok

Diagram blok tempat sampah pintar yang berbasi Arduino Uno meliputi buzzer, servo, dan ardruino yang berfungsi untuk mengetahui volume sampah dan jarak.

\begin{tabular}{ll}
\hline \multicolumn{1}{c}{ Alat } & \multicolumn{1}{c}{ Bahan } \\
\hline Lem Tembak & Kit Arduino Uno \\
Cutter & Baterai 9 Volt \\
Penggaris & Jack DC \\
Jangka & Isi lem tembak \\
Solder & Timah Solder \\
Lem kerts & Kardus \\
Cat luki & \\
\hline
\end{tabular}

Tabel 1. Alat dan bahan 


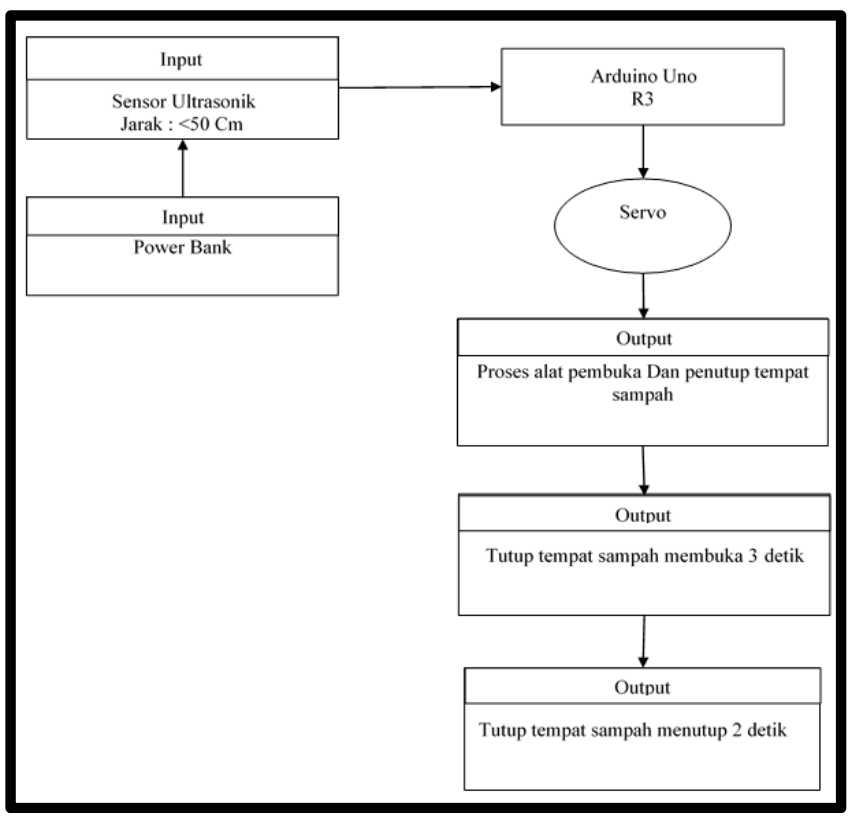

Gambar 5. Diagram Blok Desain

Keterangan:

a. Powerbank sebagai menghidupkan dan mematikan tempat sampah pintar.

b. Arduino Uno R3 penghantar program dari tempat sampah pintar.

c. Sensor HC-SRF04 untuk pendeteksi pergerakan tangan pada saat membuang sampah.

d. Motor servo sebagai pembuka dari tutup tempat sampah.

e. Buzzer sebagai sirine pemberitahuan bahwa sampah penuh.

f. LCD sebagai pemberitahuan tempat sampah penuh saat LED menyala merah dan tempat sampah kosong saat LED menyala hijau.

g. LED sebagai pemberitahuan jika

1) Berwarna hijau tandanya masih kosong.

2) Berwarna merah tandanya penuh.

3) Desain Mekanikal

4) Flowchart 


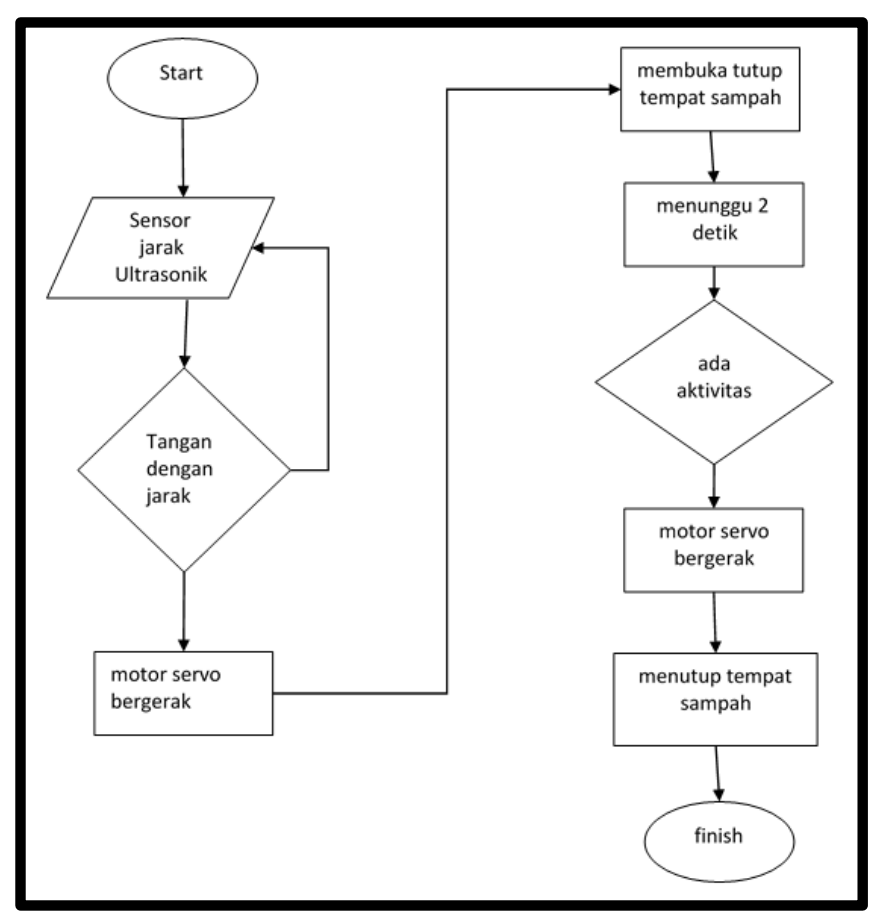

Gambar 6. Desain flowchart

Keterangan gambar 6 pada saat tempat sampah menerima sensor tangan yang diletakkan di depan sensor ultrasonic dengan jarak $5 \mathrm{~cm}-10 \mathrm{~cm}$. Sensor tersebut akan diteruskan pada motor servo dan memberikan reaksi terbukanya tutup tempat sampah pintar dengan jeda dua detik. Sampah yang akan ditampung di tempat sampah pintar dapat dimasukan kedalam. Setelah itu motor servo bergerak kembali kearah dalam sehingga tempat sampah pintar tertutup kembali. Gambar 7 merupakan posisi tempat sampah pintar pada saat belum menerima sensor/tertutup (sebelah kiri) dan posisi ketika mendapatkan sensor tempat sampah terbuka (sebelah kanan). 


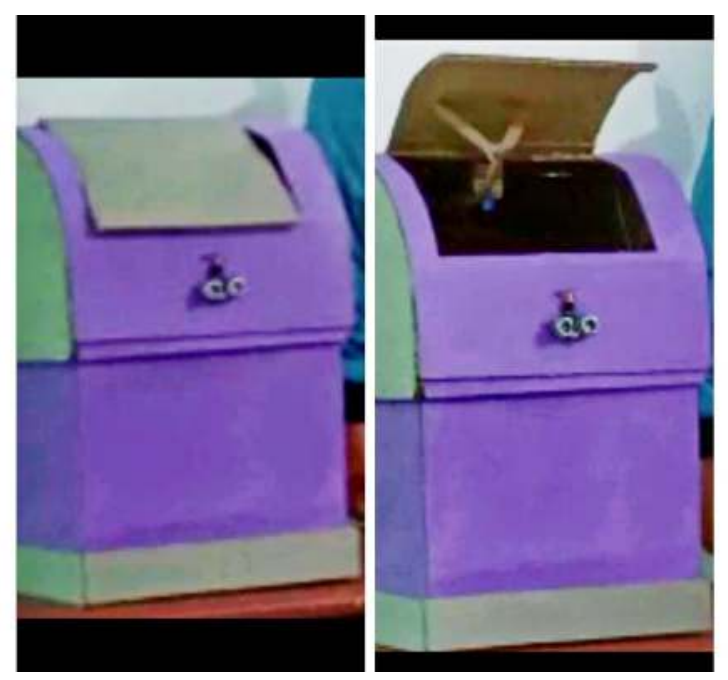

Gambar 7. Tempat Sampah Pintar

Pada perancangan dan pembuatan elektrikal, selain menggunakan Arduino Atmega328 sebagai kontrol utama, juga menggunakan komponen lain sebagai pendukung rangkaian Arduino Uno dengan tiga sensor ultrasonic (HC-SRF04).

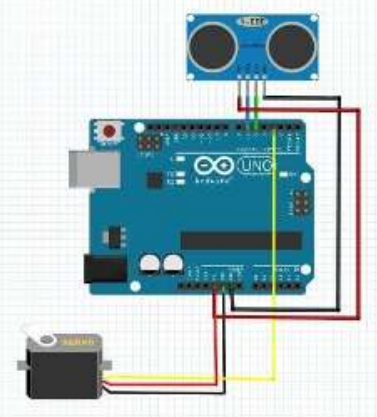

\section{Gambar 7. Rangkaian Seluruh Sistem}

\section{KESIMPULAN}

Setelah dilakukan proses pengujian dan pengambilan data selama beberapa kali, maka Sistem tempat sampah pintar berbasis arduino uno R3 dapat disimpulkan, tempat sampah pintar dengan sensor HC-SRF04 berbasis arduino uno R3 telah mampu bekerja menjalankan fungsinya dengan baik, tempat sampah pintar dengan sensor HC-SRF04 berbasis arduino uno R3 ini dapat mendeteksi pergerakan dengan jarak $10 \mathrm{~cm}$ setelah itu secara otomatis servo akan membuka tutup tempat sampah, tempat sampah pintar dengan sensor HC-SRF04 berbasis arduino uno R3 ini dapat mendeteksi volume sampah jika kondisi tempat sampah penuh maka akan mengeluarkan suara sirine. Lain hal dengan prototype tempat sampah otomatis berbasis mikrokontroler ATMega328, bahwa pengendali gerak tutup tempat sampah menggunakan gerak motor servo dari ukuran gerak $0^{\circ}$ ke $50^{\circ}$ dan menggunakan sensor ultrasonic sebagai pendeteksi objek gerak yang ada di depannya dengan jarak $30 \mathrm{~cm}$. dengan pemasangan sensor detektor asap dan juga Penggunaan sensor infrared yang telah terpasang pada tutup tempat sampah sebagai sensor deteksi objek yang dapat berfungsi pada jarak $5 \mathrm{~cm}$ (Utomo \& Chusna, 2019). 


\section{UCAPAN TERIMA KASIH}

Tim peneliti mengucapkan terima kasih atas izin Allah SWT dengan karunia dan kemudahan-Nya, tim peneliti bisa menyelesaikan penelitian ini. Serta dukungan dan doa dari semua pihak yang telah membantu, baik itu para mahasiswa dan rekan-rekan dosen di Universitas Banten Jaya.

\section{DAFTAR PUSTAKA}

Arsada, B. (2017). Aplikasi Sensor Ultrasonik Untuk Deteksi Posisi Jarak Pada Ruang Menggunakan Arduino Uno. Jurnal Teknik Elektro, 6(2), 1-8.

Budiarso, Z., \& Prihandono, A. (2015). Implementasi Sensor Ultrasonik Untuk Mengukur Panjang Gelombang Suara Berbasis Mikrokontroler. Jurnal Teknologi Informasi DINAMIK, 20(2), 171-177.

Hidayat, C. R., \& Syahrani, F. D. (2017). Perancangan Sistem Kontrol Arduino Pada Tempat Sampah Menggunakan Sensor Pir Dan Sensor Ultrasonik. Jurnal Voice of Informatics, 6, 65-75. Retrieved from https://voi.stmiktasikmalaya.ac.id/index.php/voi/article/view/82

Kholifah, U. N. (2015). ROBOT PEMBERSIH LANTAI BERBASIS ARDUINO UNO DENGAN SENSOR Abstrak Perkembangan Ilmu pengetahuan dan teknologi saat ini sangatlah pesat, terutama di bidang teknologi elektronika mempengaruhi kehidupan masyarakat untuk melangkah lebih maju, praktis dan si. Jurnal Teknologi Elektro, Universitas Mercu Buana, 6(3), 136-143.

Nugroho, E. C., Pamungkas, A. R., \& Purbaningtyas, I. P. (2018). Rancang Bangun Alat Pemilah Sampah Otomatis Berbasis Arduino Mega 2560. Go Infotech: Jurnal IImiah STMIK AUB, 24(2), 124. https://doi.org/10.36309/goi.v24i2.96

Nusyirwan, D. (2020). Tong Sampah Pintar Dengan Perintah Suara Guna Menghilangkan Perilaku Siswa Membuang Sampah Sembarangan Di Sekolah. Jurnal Teknoinfo, 14(1), 48. https://doi.org/10.33365/jti.v14i1.336

Prayitno, A., \& Safitri, Y. (2015). Pemanfaatan Sistem Informasi Perpustakaan Digital Berbasis Website Untuk Para Penulis. Indonesian Journal on Software Engineering, 1(1), 1-10. Retrieved from file:///C:/Users/user/Downloads/592-1277-1-PB.pdf

Putra, H. P., \& Wahid, S. N. (2019). Pembuatan Trainer Tempat Sampah Otomatis Guna Menyiasati Masalah Sampah Di Lingkungan Masyarakat (Making Automatic Trash Trainer To Get Rid of Waste Problems in the Community Environment). JEEE-U (Journal of Electrical and Electronic Engineering-UMSIDA), 3(1), 120. https://doi.org/10.21070/jeee-u.v3i1.2087

Utomo, W., \& Chusna, N. L. (2019). Pembuatan Prototipe Tempat Sampah Otomatis Berbasis Mikrokontroler Atmega328. 22(1), 62-68.

Wuryanto, A., Hidayatun, N., Rosmiati, M., \& Maysaroh, Y. (2019). Perancangan Sistem Tempat Sampah Pintar Dengan Sensor HCRSF04 Berbasis Arduino UNO R3. Paradigma - Jurnal Komputer Dan Informatika, 21(1), 55-60. https://doi.org/10.31294/p.v21i1.4998 